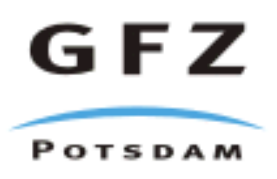

Originally published as:

Stott, L., Cannariato, K., Thunell, R., Haug, G. H., Koutavas, A., Lund, S. (2004): Decline of surface temperature and salinity in the western tropical Pacific Ocean in the Holocene epoch.

- Nature, 431, 56-59

DOI: $10.1038 /$ nature02903 


\title{
Decline of surface temperature and salinity in the western tropical Pacific Ocean in the Holocene epoch
}

Lowell Stott $^{1}$, Kevin Cannariato ${ }^{1}$, Robert Thunell ${ }^{2}$, Gerald H. Haug ${ }^{3}$, Athanasios Koutavas ${ }^{4}$ and Steve Lund ${ }^{1}$

1. Department of Earth Sciences, University of Southern California, Los Angeles, California 90089, USA

2. Department of Geological Sciences, University of South Carolina, Columbia, South Carolina 29205, USA

3. Geoforschungszentrum Potsdam, D-14473 Potsdam, Germany

4. Department of Earth, Atmospheric, and Planetary Sciences, Massachusetts Institute of Technology, 77 Massachusetts Avenue, Cambridge, Massachusetts 02139, USA

Correspondence to: Lowell Stott ${ }^{1}$ Email: stott@usc.edu

The foraminiferal $s^{18} \mathrm{O}$ and $\mathrm{Mg} / \mathrm{Ca}$ data are available at http://www.ngdc.noaa.gov.

\begin{abstract}
In the present-day climate, surface water salinities are low in the western tropical Pacific Ocean and increase towards the eastern part of the basin ${ }^{1}$. The salinity of surface waters in the tropical Pacific Ocean is thought to be controlled by a combination of atmospheric convection, precipitation, evaporation and ocean dynamics ${ }^{2}$, and on interannual timescales significant variability is associated with the El Niño/Southern Oscillation cycles. However, little is known about the variability of the coupled ocean-atmosphere system on timescales of centuries to millennia. Here we combine oxygen isotope and $\mathrm{Mg} / \mathrm{Ca}$ data from foraminifers retrieved from three sediment cores in the western tropical Pacific Ocean to reconstruct Holocene sea surface temperatures and salinities in the region. We find a decrease in sea surface temperatures of $\approx 0.5^{\circ} \mathrm{C}$ over the past $10,000 \mathrm{yr}$, whereas sea surface salinities decreased by $\approx 1.5$ practical salinity units. Our data imply either that the Pacific basin as a whole has become progressively less salty or that the present salinity gradient along the Equator has developed relatively recently.
\end{abstract}

On interannual timescales, the El Niño/Southern Oscillation (ENSO) causes large changes in salinity over the equatorial Pacific as the warm, low-salinity waters from the western tropical Pacific (WTP) are advected east into the central Pacific. This redistribution of warm waters along the Equator also alters the locus of atmospheric convection and seems to enhance the transport of heat from the tropics to higher latitudes ${ }^{2,3,4}$. On longer timescales it is possible that other modes of variability have existed that can only be ascertained through analysis of long proxy records.

We reconstructed WTP sea surface temperature (SST) and the stable oxygen isotope composition of surface water $\left({ }^{18} \mathrm{O}_{\mathrm{SW}}\right)$ variability through the Holocene as a method of determining how the freshwater flux and ocean dynamics varied in the past and how that variability affected salinity gradients in the tropics. In the WTP, sea surface salinity (SSS) and ${ }^{18} \mathrm{O}_{\mathrm{SW}}$ are correlated, reflecting the balance between the freshwater flux (evaporation precipitation) and salt advection by means of ocean transport. A change in the ${ }^{18} \mathrm{O}$ of fresh water or the amount of fresh water falling on the ocean relative to inputs of salty water by means of ocean dynamics changes the salinity and also $s^{18} \mathrm{O}_{\mathrm{SW}}$. Groundwater $s^{18} \mathrm{O}$ values of early, middle and late Holocene age from sites in the WTP all have the same value as present- 
day monsoon rainwater, indicating there has not been a change in the isotopic value of fresh water falling on the ocean over this period ${ }^{5}$. We therefore expect WTP ${ }_{8}^{18} \mathrm{O}_{\mathrm{SW}}$ values to have been controlled during the Holocene primarily by the combined effects of changing freshwater flux (the amount effect) and the flux of salty water through the WTP by means of ocean dynamics. Today these two processes result in a surface water ${ }^{18} \mathrm{O} /$ salinity relationship that has a slope of between $0.3 \%$ and $0.4 \%$ per practical salinity unit (p.s.u. $)^{6,7}$.

The ${ }^{18} \mathrm{O}_{\mathrm{SW}}$ is incorporated into $\mathrm{CaCO}_{3}$ shells of planktonic foraminifers that inhabit the surface ocean. To reconstruct past changes in ${ }^{18}{ }^{18} \mathrm{O}_{\mathrm{SW}}$ we analysed the stable oxygen isotopic composition and $\mathrm{Mg} / \mathrm{Ca}$ of calcium carbonate produced by the surface-dwelling planktonic foraminifer Globigerinoides ruber. The carbonate shells of this foraminifer accumulated on the sea floor throughout the Holocene and became part of the sediment archive that was cored by the IMAGES programme in 1998 (Fig. 1). Using foraminiferal samples from three WTP IMAGES cores we reconstructed a continuous record of sea surface temperatures with $\mathrm{Mg} / \mathrm{Ca}$ palaeothermometry ${ }^{8}$, which has an estimated uncertainty of $\pm 1{ }^{\circ} \mathrm{C}$. We also measured the $\mathrm{s}$ ${ }^{18} \mathrm{O}_{\mathrm{C}}$ of the same foraminiferal material. The isotopic measurements have an analytical precision of $\pm 0.1 \%$ and a practical sample reproducibility of about $\pm 0.1 \%$. Combining the temperature estimates with the measured values of G. ruber ${ }^{18} \mathrm{O}_{\mathrm{C}}$, we derived values of : ${ }^{18} \mathrm{O}_{\mathrm{SW}}$ from the carbonate palaeotemperature equation (Supplementary Information).

Our measurements are combined with previously published data from equatorial Pacific ODP Site 806 (ref. 9) to examine how surface water properties in the WTP between Indonesia and the open Pacific have varied through the Holocene epoch (Fig. 1). Samples from the Indonesian sites provide a multidecadal (MD81 and MD76) to centennial (MD70) temporal resolution through the entire Holocene, whereas the open-ocean ODP Site 806 record is of millennial resolution. Other high-quality late Pleistocene and early Holocene records are available from the Sulu Sea ${ }^{10}$ but do not provide a continuous record through the entire Holocene. The sites discussed here are all located between $6^{\circ} \mathrm{N}$ and $11^{\circ} \mathrm{S}$ (Fig. 1) and the chronology for each core is based on radiocarbon dating of fossil carbonates.

Between $10 \mathrm{kyr}$ ago and the late Holocene, the $5^{18} \mathrm{O}$ of $G$. ruber $\left({ }^{18} \mathrm{O}_{\mathrm{C}}\right)$ at each of the WTP sites decreased by $\approx 0.4 \%$ (Fig. 1). Because this trend occurred after Northern Hemisphere ice sheets had mostly retreated, a change in ice volume cannot account for the large change in $\delta$ ${ }^{18} \mathrm{O}_{\mathrm{C}}$ during the late Holocene ${ }^{11}$. The trend in ${ }^{18} \mathrm{O}_{\mathrm{C}}$ must reflect either SST warming through the Holocene, which produces a smaller isotope fractionation and lower $s^{18} \mathrm{O}$ values in calcium carbonate, or a decrease in the local ${ }^{18} \mathrm{O} /{ }^{16} \mathrm{O}$ of surface waters. The $\mathrm{Mg} / \mathrm{Ca}$-derived SSTs constrain how much of the ${ }^{18} \mathrm{O}$ trend can be attributed to temperature change. Our SST estimates indicate that surface waters across the WTP were warmest in the early Holocene ( $~$ $29.5^{\circ} \mathrm{C}$ ) and have cooled by $\approx 0.5^{\circ} \mathrm{C}$ since $10 \mathrm{kyr}$ ago (Fig. 2). This seems to be a robust feature of each of the records between $6^{\circ} \mathrm{N}$ and $11^{\circ} \mathrm{S}$ and is therefore unlikely to be solely a result of summer isolation changes associated with the precessional cycle. Changes in cloud albedo, evaporation and ocean dynamics arising from the precessional forcing might have contributed to the change in $\mathrm{SST}^{12}$. But on the basis of these data alone, we cannot ascertain how these factors combined to cause the higher temperatures during the early Holocene. Nonetheless, the trend in SST does not explain the decreasing foraminiferal ${ }^{18} \mathrm{O}_{\mathrm{C}}$ values between the middle to late Holocene. This trend must reflect a change in the ${ }_{8}^{18} \mathrm{O}_{\mathrm{SW}}$ and surface salinity during the Holocene. To estimate the magnitude of the salinity change since the early Holocene we stacked the WTP ${ }_{s}^{18} \mathrm{O}_{\mathrm{C}}$ and $\mathrm{Mg} / \mathrm{Ca}$ records, averaging the data at 250$\mathrm{yr}$ intervals. The stacked data were then used to calculate ${ }_{8}^{18} \mathrm{O}_{\mathrm{SW}}$. Since ${ }^{\pi *} 8 \mathrm{kyr}$ ago, ${ }_{8}^{18} \mathrm{O}_{\mathrm{SW}}$ 
values have decreased in the WTP by $0.5 \%$ (Fig. 3). On the basis of the modern $5^{18} \mathrm{O}-$-salinity relationship ${ }^{6,7}$, a decrease in ${ }_{8}^{18} \mathrm{O}_{\mathrm{SW}}$ of $0.5 \%$ reflects a decease in surface salinity of between 1 and 1.5 p.s.u. This observation implies that in the early Holocene WTP surface water was as salty as surface water in the south central equatorial Pacific today (more than 35.2 p.s.u.). This observation further implies that if the salinities in the central and eastern equatorial Pacific have not changed in association with those in the WTP, the salinity gradient that exists today across the tropical Pacific would have been absent or significantly reduced in the early to middle Holocene.

Higher $\mathrm{s}^{18} \mathrm{O}_{\mathrm{SW}}$ values have also been recognized in a middle Holocene coral record from the Great Barrier reef ${ }^{13}$, indicating these higher salinities extended over large portions of the WTP (Fig. 1). The higher ${ }_{8}^{18} \mathrm{O}_{\mathrm{SW}}$ values from the Great Barrier Reef were interpreted to reflect enhanced evaporation over that portion of the WTP during the middle Holocene. We find it difficult to reconcile the higher $3^{18} \mathrm{O}_{\mathrm{SW}}$ values that we observe in the early to middle Holocene in the northern WTP with increased evaporation because the surface salinities in this region are so strongly influenced by summer monsoon precipitation, which most climate models indicate would have been enhanced in the middle Holocene by increased solar heating in boreal summer associated with the precessional forcing ${ }^{14}$. Today, the northern WTP receives in excess of $2 \mathrm{~m}$ of rainfall during the summer monsoon. The isotopic composition of this water is about $-6.5 \%$. Groundwater of early to late Holocene age from the Philippines has the same $s^{18} \mathrm{O}_{\text {SMOW }}$ as modern rainwater, indicating that the source of moisture to the region has not changed during the Holocene ${ }^{5}$. Therefore, if the isotopic composition of rain has not changed, an isotope mass balance calculation (with no change in ocean transport) would require there to have been a decrease in rainfall of more than $2 \mathrm{~m}$ (the entire seasonal rainfall amount today) to shift a $25-\mathrm{m}$-thick ocean mixed layer by the observed $0.5 \%$. There is no evidence for such a drastic decrease in monsoon rainfall during the Holocene. In fact, the early to middle Holocene groundwater $3^{18} \mathrm{O}_{\text {SMOW }}$ values imply that there has been a persistent and strong monsoon system throughout the Holocene ${ }^{1}$. We conclude that the increased ${ }^{18} \mathrm{O}_{\mathrm{SW}}$ values in the early Holocene were not due to increased evaporation but rather were the result of either increased westward advection of salty waters through the WTP, which would imply very different salinity gradients along the Equator compared with today or that the Pacific surface waters as a whole have become progressively less salty.

With only a limited number of high-resolution Holocene ${ }^{18} \mathrm{O}_{\mathrm{SW}}$ records available from other parts of the global ocean it is not possible to assess whether the observed changes in the WTP reflect a larger, basin-scale change in the isotopic composition of the ocean. However, numerical model simulations have suggested that sustained shifts in the location of the Intertropical Convergence Zone (ITCZ) over the tropical Atlantic Ocean would probably affect the vapour flux to the Pacific, and change the fresh water as well as the isotopic balance over the oceans ${ }^{15}$. A persistent displacement of the ITCZ to more northerly latitudes in summer would act to trap isotopically light vapour within the Atlantic basin and decrease the vapour gain in the Pacific. The salinity and ${ }_{5}^{18} \mathrm{O}$ changes we document from the WTP occurred in close association with the precessional cycle and with enhanced solar heating in the northern tropics during the early Holocene, which would have tended to pull the ITCZ north off its present summer latitude ${ }^{14}$. Over the course of millennia a northerly bias in the latitude of the ITCZ and reduced vapour transport between the oceans could have affected the isotopic composition of Pacific surface waters. At present there are no continuous SSS records from the tropical Atlantic and eastern Pacific that span the entire Holocene and provide the same temporal resolution that is available for the WTP. Nonetheless, previous 
studies have documented an early Holocene pluvial over North Africa and a stronger Indian Ocean summer monsoon in response to Earth's precessional cycle ${ }^{16,17}$. Cariaco Basin sediments also contain evidence of higher rainfall in northern South America during the early Holocene, with increasingly arid conditions developing during the past 5,000 yr (ref. 18). These data all point to tropic-wide changes in the hydrological cycle that have been attributed to a more northerly position of the ITCZ during the early Holocene in response to changes in solar radiation associated with the precessional cycle. Data from other parts of the Pacific and Atlantic will now be required for an assessment of whether the changes in the hydrologic cycle affected the salinity gradient between the Pacific and Atlantic Oceans. If so, millennial to centennial scale changes in Holocene ocean thermohaline circulation would be directly affected by ocean-atmosphere processes that have occurred in the tropics.

\section{References}

1. Levitus, S. \& Boyer, T. P. World Ocean Atlas 1994 Vol. 3, Salinity (NOAA Atlas NESDIS, US Department of Commerce, Washington DC, 1994)

2. Cronin, M. F. \& McPhaden, M. J. Upper ocean salinity balance in the western equatorial Pacific. J. Geophys. Res. 103, 27567-27587 (1998)

3. Sun, D.-Z. \& Trenberth, K. E. Coordinated heat removal from the equatorial Pacific during the 1986-87 El Niño. Geophys. Res. Lett. 25, 2659-2662 (1998)

4. McPhaden, M. J. Genesis and evolution of the 1997-98 El Niño. Science 283, 950-954 (1999)

5. Aggarwal, P. K., Fröhlich, K., Kulkarni, K. M. \& Gourcy, L. L. Stable isotope evidence for moisture sources in the Asian summer monsoon under present and past climate regimes. Geophys. Res. Lett. 31, doi:10.1029/2004GL019911 (2004).

6. Fairbanks, R. G. et al. Evaluating climate indices and their geochemical proxies measured in corals. Coral Reefs 16, S93-S100 (1997)

7. Morimoto, M. et al. Salinity records for the 1997-98 El Niño from Western Pacific corals. Geophys. Res. Lett. 29, doi:10.1029/2001GL013521 (2002)

8. Nürnberg, D., Bijma, J. \& Hemleben, C. Assessing the reliability of magnesium in foraminiferal calcite as a proxy of water mass temperature. Geochim. Cosmochim. Acta 60, 803-814 (1996)

9. Lea, D. W., Pak, D. K. \& Spero, H. J. Climate impact of late Quaternary equatorial Pacific sea surface temperature variations. Science 289, 1719-1724 (2000)

10. Oppo, D. W., Linsley, B. K., Rosenthal, Y., Dannenmann, S. \& Beaufort, L. Orbital and suborbital climate variability in the Sulu Sea, western tropical Pacific. Geochem. Geophys. Geosyst. 4, doi:1029/2001GC000260 (2003).

11. Fairbanks, R. A 17,000-year glacio-eustatic sea level record: influence of glacial melting rates on the Younger Dryas event and deep-ocean circulation. Nature 342, 637-642 (1989)

12. Clement, A. C., Seager, R. \& Cane, M. A. Orbital controls on the El Niño/Southern Oscillation and the tropical climate. Paleoceanography 14, 441-456 (1999)

13. Gagan, M. K. et al. Temperature and surface-ocean water balance of the midHolocene tropical western Pacific. Science 279, 1014-1018 (1998)

14. Liu, Z., Kutzbach, J. \& Wu, L. Modeling climate shift of El Niño variability in the Holocene. Geophys. Res. Lett. 27, 2265-2268 (2000)

15. Schmittner, A., Appenzeller, Z. \& Stocker, T. F. Enhanced Atlantic freshwater export during El Niño. Geophys. Res. Lett. 27, 1163-1166 (2000)

16. Prell, W. L. \& Van Campo, E. Coherent response of Arabian Sea upwelling and pollen transport to late Quaternary monsoonal winds. Nature 323, 526-528 (1986) 
17. DeMenocal, P., Ortiz, J., Guilderson, T. \& Sarnthein, M. Coherent high- and lowlatitude climate variability during the Holocene warm period. Science 288, 2198-2202 (2000)

18. Haug, G. H. et al. Southward migration of the Intertropical Convergence Zone through the Holocene. Science 293, 1304-1308 (2001)

19. Waelbroeck, C. et al. Sea-level and deep water temperature changes derived from benthic foraminifera isotopic records. Quat. Sci. Rev. 21, 295-305 (2002)

\section{Acknowledgements}

We thank M. Rincon for analytical assistance. This research was supported by the US-NSFOCE. 
Figure 1: Western tropical Pacific marine sediment core locations and corresponding climate records.

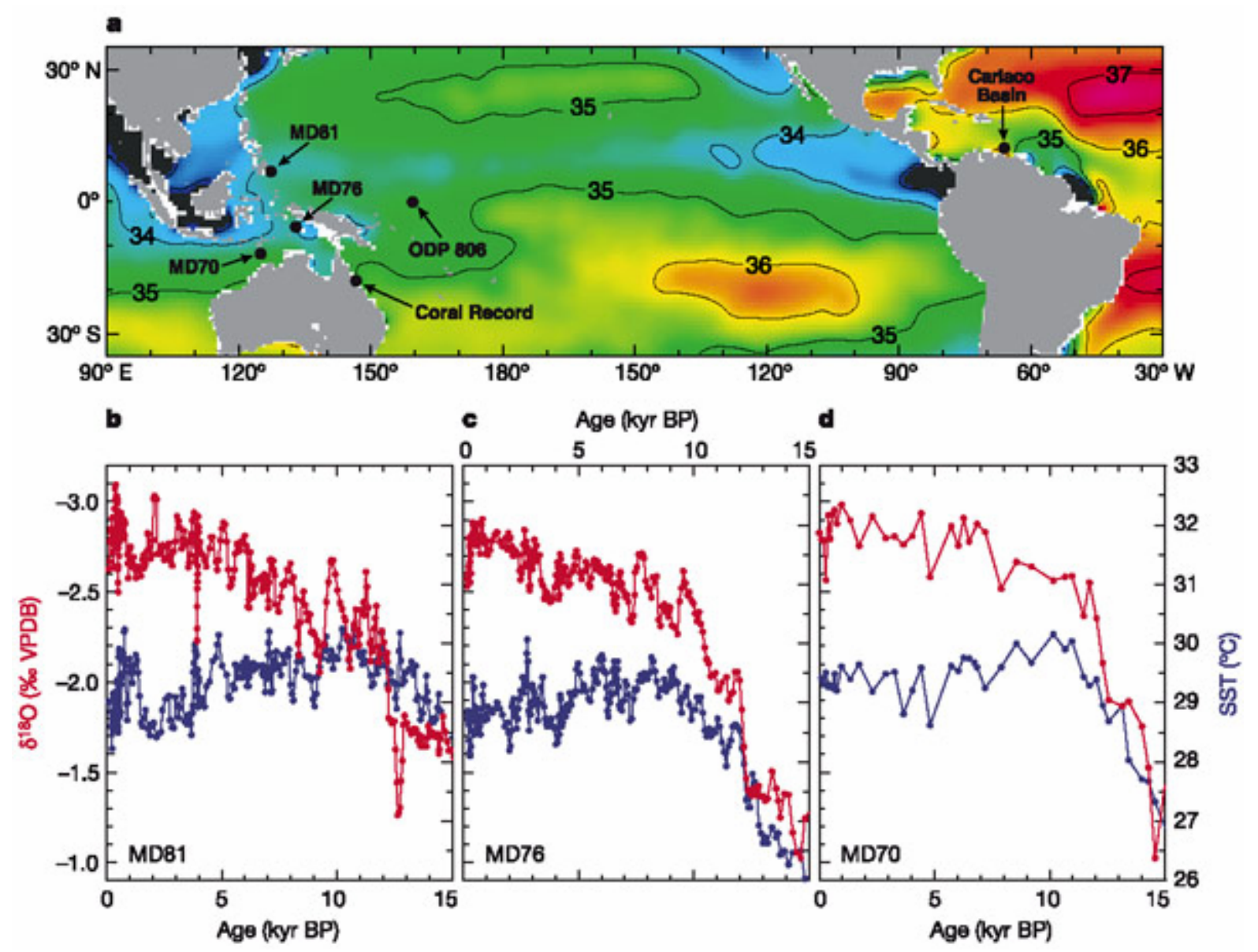

a, Map of mean annual surface salinities in the tropical Pacific ${ }^{1}$ illustrating the location of IMAGES MD core locations from which the oxygen isotope (red in $\mathbf{b}-\mathbf{d}$ ) and $\mathrm{Mg} / \mathrm{Ca}-$ palaeoSST records (blue in $\mathbf{b}-\mathbf{d}$ ) were generated for this study. $\mathbf{b}-\mathbf{d}$, Results from individual sites: b, MD81; c, MD76; d, MD70. The data from sites MD81 and MD76 have been smoothed with a 3-point running mean. 
Figure 2: Reconstructed records for WTP sites.
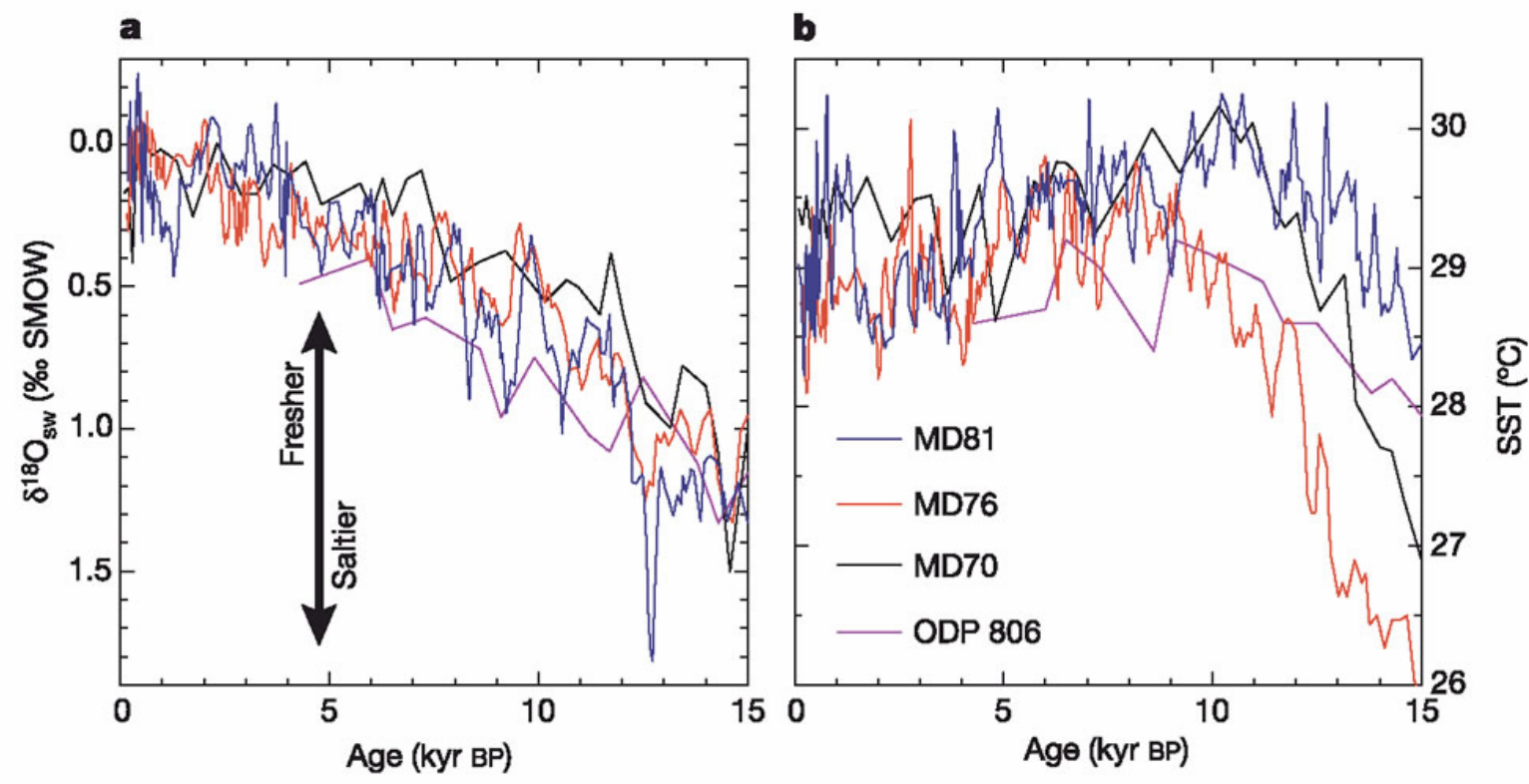

a, $s^{18} \mathrm{O}_{\mathrm{sw}} ; \mathbf{b}, \mathrm{SST}$. The $\mathrm{s}^{18} \mathrm{O}_{\mathrm{sw}}$ values were calculated by solving the calcite palaeotemperature equation for ${ }^{18} \mathrm{O}_{\mathrm{sw}}$ using the foraminiferal $\mathrm{Mg} / \mathrm{Ca}$ temperatures and the $\mathrm{s}^{18} \mathrm{O}$ values. Blue, MD81; red, MD76; black, MD70; purple, ODP 806. 
Figure 3: Stacked (average value) (a) $\sigma^{18} \mathrm{O}_{\mathrm{sw}}$ and (b) SST records from Fig. 2, with $1 \sigma$ uncertainty envelope (grey).

a

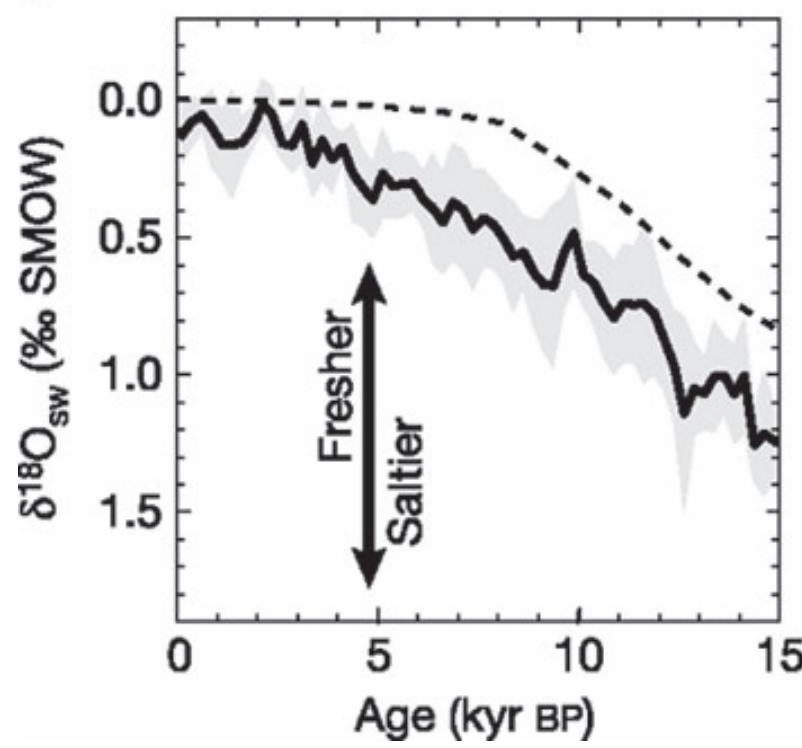

b

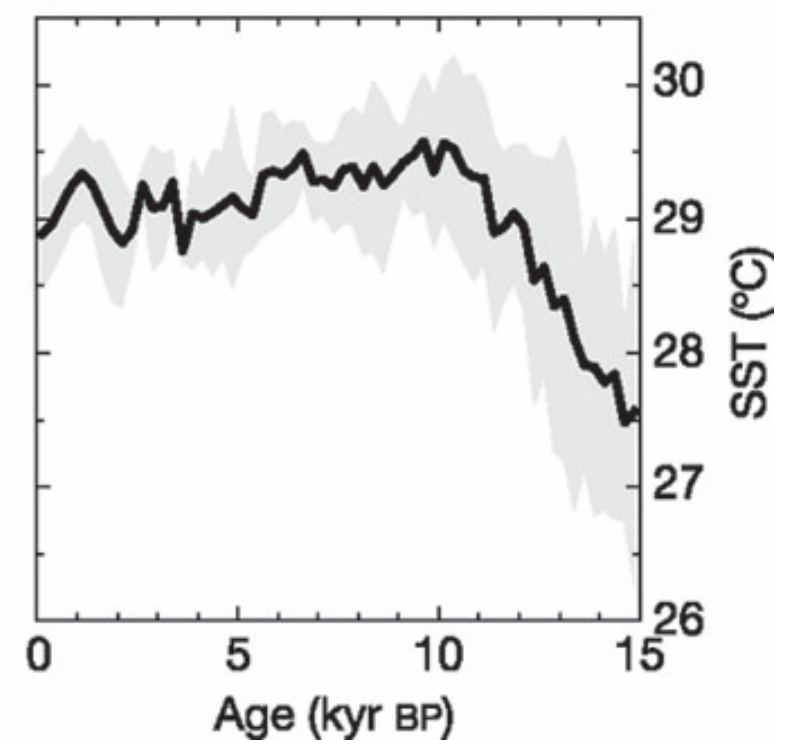

Dashed line in panel $\mathbf{a}$ is the ${ }^{18} \mathrm{O}_{\mathrm{sw}}$ change due to the melting ice sheets reconstructed from stacked benthic foraminiferal $\delta^{18} \mathrm{O}$ records ${ }^{19}$. 